Gut, 1971, 12, 393-398

\title{
Ganglion cell changes in experimental stenosis of the gut
}

\author{
R. J. EARLAM \\ From The London Hospital, Whitechapel, London
}

SUMMARY Teflon mesh was wrapped around the terminal ileum of dogs to cause a partial obstruction. Both smooth muscle layers became thickened in the gut proximal to the constriction, but the circular muscle was more hypertrophied than the longitudinal. The cells in Auerbach's plexus were stained by an indoxyl esterate technique in $100 \mu$ sections and counted. The number of ganglion cells related to muscle mass was decreased above the constriction. Although some ganglion cells increased in size there was no evidence of any increase in number.

An increase in the number of ganglion cells has been observed in both ulcerative colitis (Storsteen, Kernohan, and Bargen, 1953) and regional enteritis (Davis, Dockerty, and Mayo, 1955), when the gut is overactive. Experimentally, a similar increase has also been observed proximal to a stenosis (Filogamo and Vigliani, 1954; Benninghoff, 1951). These authors themselves have recognized that if the number of ganglion cells were really increased, it would represent the only known example of multiplication of neurones after birth and would consequently have great biological significance. Since no mitoses were ever seen in these neurones, it was suggested that the increase represented the development of certain unspecified cells into recognizable ganglion cells. The purpose of the present study was to reproduce experimental stenosis in the canine small gut and examine the subsequently dilated gut with a technique specially developed for counting large numbers of ganglion cells easily, to see whether there was any actual increase in the number.

\section{Methods}

Seven healthy adult mongrel dogs, weighing between 14 and $22 \mathrm{~kg}$, were operated upon in an attempt to produce experimental stenosis of the small bowel. Teflon mesh was placed around the small intestine, between 15 and $30 \mathrm{~cm}$ proximal to the ileocaecal valve, and stitched together on the mesenteric border without interrupting the blood supply. Occasional further sutures fixed the mesh at its periphery so that a stenotic lesion $5 \mathrm{~cm}$ long was established. The degree of stenosis could be controlled by Received for publication 9 March 1971. folding the mesh in upon itself, but at the original operation no attempt was made to reduce the diameter by more than half. The dogs subsequently ate a normal kennel diet. If they had signs of intestinal obstruction clinically they were sacrificed. Two were operated upon again 12 and 20 days after the initial attempt to produce stenosis, and the Teflon constriction was tightened.

At various intervals between seven and 63 days the dogs were sacrificed. The gut was immediately removed and split longitudinally through the stenotic area. The mean circumference of the fresh specimen was measured distal to the lesion whereas proximally its maximum and not the mean circumference was taken. A thin ring of gut, $1 \mathrm{~cm}$ wide, was removed from above and below the stenosis. The distal specimen was always obtained from at least $3 \mathrm{~cm}$ below this area, and the proximal specimen was selected from the site of maximal dilatation. The mucosa was removed from the specimens by scraping with a scalpel blade, so that muscle alone remained.

The two pieces were then frozen and $100 \mu$ sections were cut parallel to the serosal surfaces in the plane of Auerbach's plexus, so that longitudinal muscle was always removed before the circular layer. The sections were stained with an indoxyl esterase technique (Holt and Withers, 1952) which had previously been specially developed for selective staining of ganglion cells in thick preparations (Earlam, Schlegel, and Ellis, 1967). After mounting in thick Canada balsam the section could be laid out on a microscope slide (Fig. 1), but if the circumference was too great it had to be cut into two or three parts. The architecture of the serial cuts 


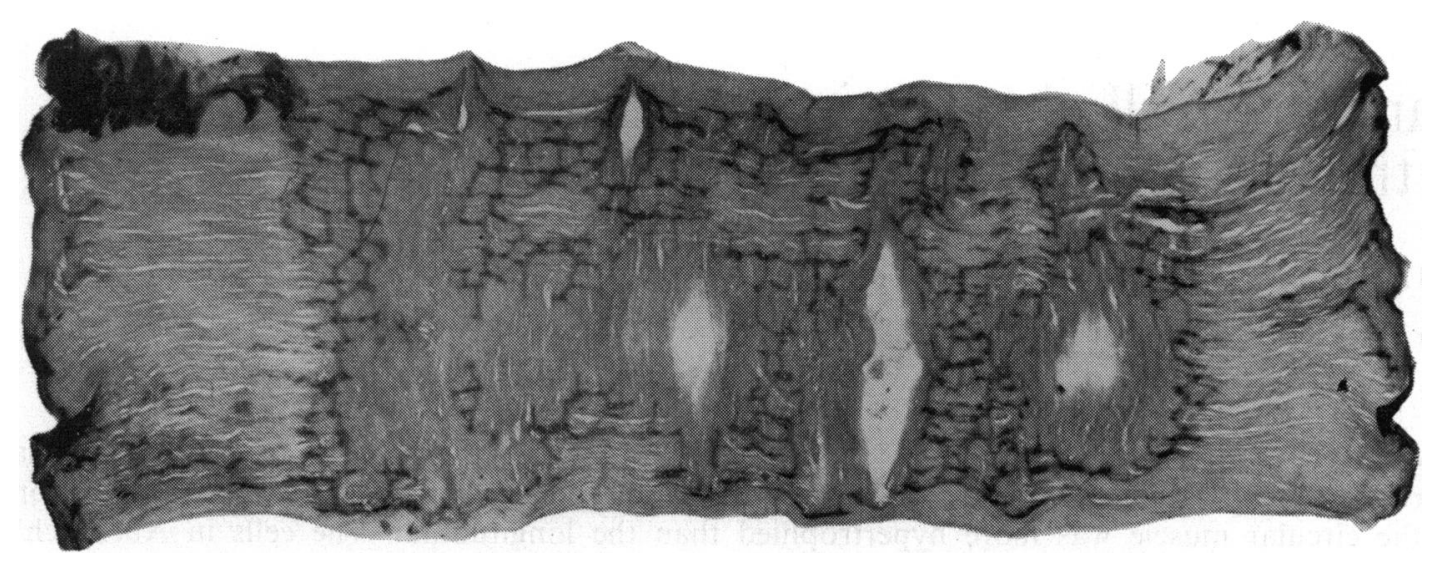

Fig. 1. A $100 \mu$ section, cut parallel to the plane of Auerbach's plexus, showing both longitudinal and circular muscle with the intervening nerve meshwork stained by the indoxyl esterase technique.

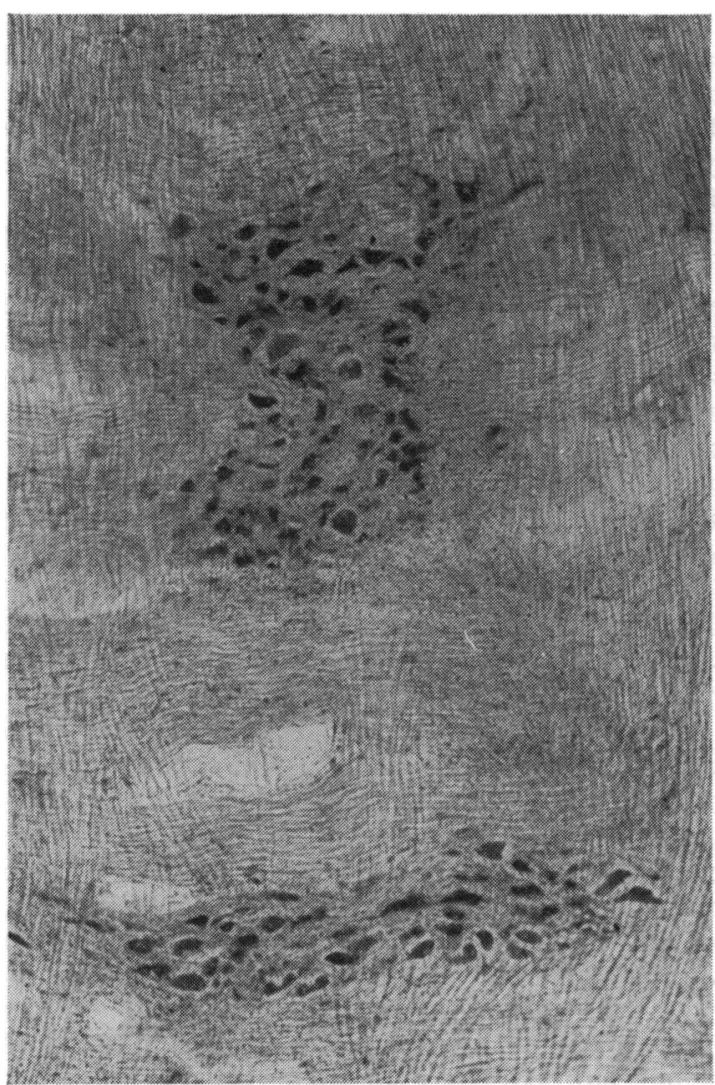

Fig. 2. Two separate collections of cells in Auerbach's plexus stained with indoxyl esterase. was easily identifiable when they were all in a row next to each other, and the thickness of both the longitudinal and circular muscle could be calculated even though the sections had not been perfectly cut in the plane of Auerbach's plexus. Each slide was mounted in a photographic enlarger and a black and white enlargement made, approximately $30 \times 10 \mathrm{~cm}$. With this overall map of the slide as a guide, the ganglion cells in each Auerbach's plexus were counted (Fig. 2) and the total number seen on any one slide was calculated. The volume of muscle in any one series of slides was obtained from the size and thickness of the total sections and an assessment of ganglion cells per $\mathrm{mm}^{3}$ was made for each specimen above and below the stenosis.

Further sections $(7 \mu)$ cut vertically to the plane of Auerbach's plexus were stained with haematoxylin and eosin (Fig. 3). The differences in morphology of individual ganglion cells were seen more clearly from these slides than the thick sections.

\section{Results}

Two out of the seven dogs died in the phase immediately after operation (one from the anaesthetic and the other from peritonitis associated with a leak through the bowel wall where a stitch had cut through). The remainder survived seven to 63 days after the initial operation, including the two which had had the stenosis tightened on the 13th day $(\operatorname{dog} 3)$ and 20th day $(\operatorname{dog} 2)$. Figure 4 shows that the circumference of the bowel proximal to the lesion could increase by a factor of 3 , without 


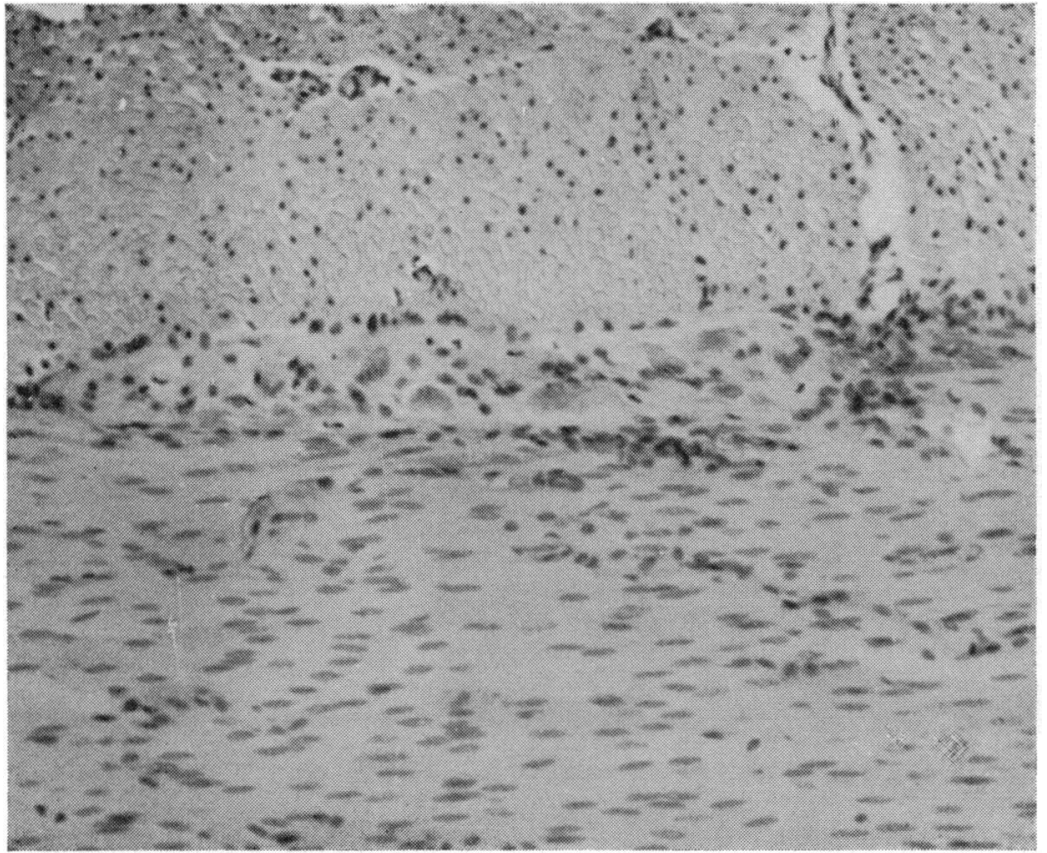

Fig. 3a.

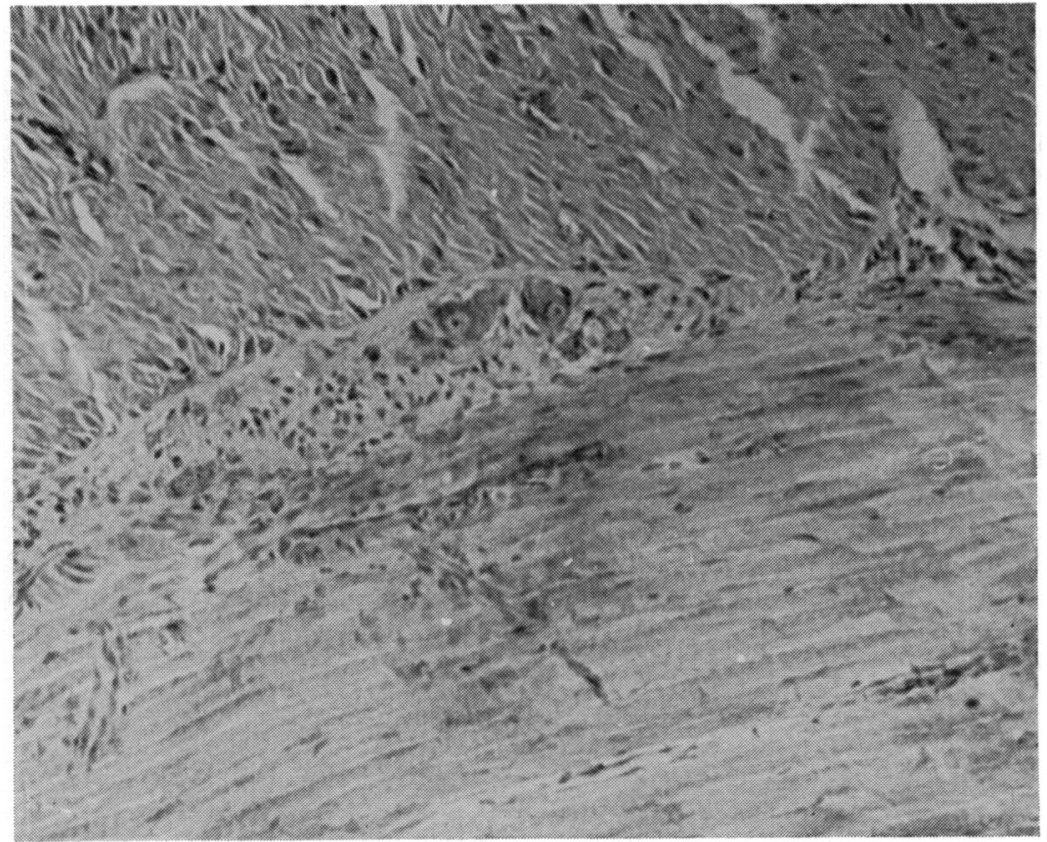

Fig. 3h,

Fig. 3. a Poststenotic bowel showing a normal Auerbach's plexus stained with haematoxylin and eosin. b Prestenotic bowel stained similarly and with the same magnification demonstrating the increased thickness of the smooth muscle and enlargement of the individual ganglion cells. 


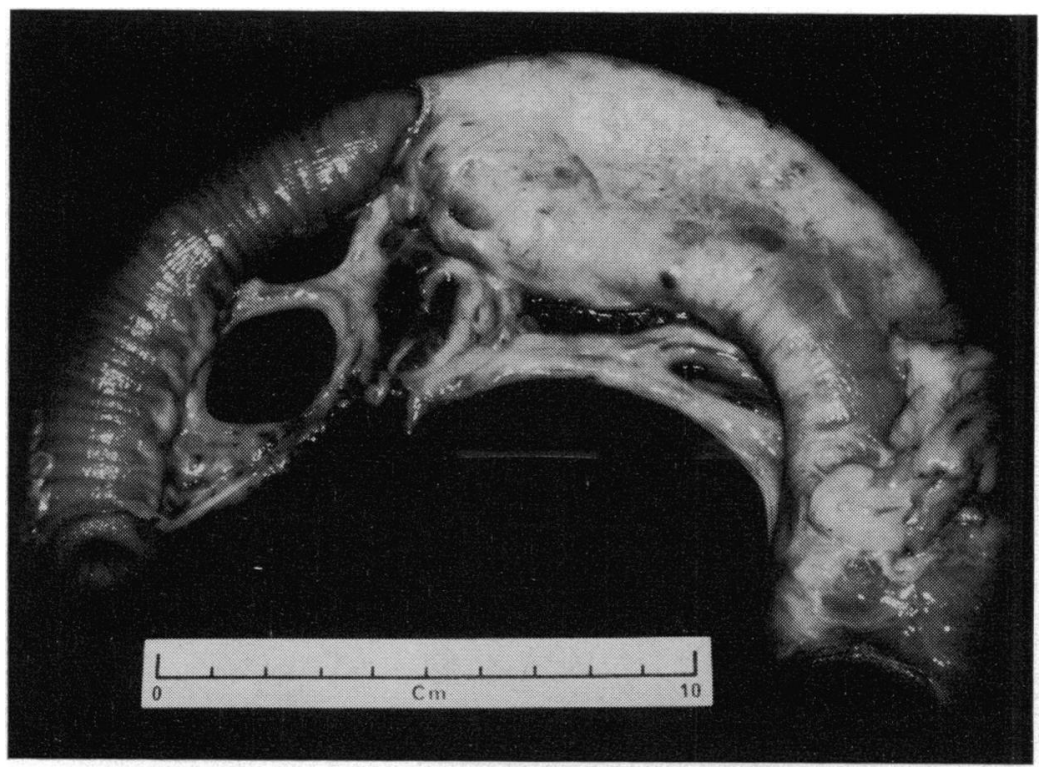

Fig. 4. The increase in the diameter of the gut is seen on the right proximal to the obstruction. The Teflon mesh is covered with white fibrous tissue.

causing clinical signs of obstruction. In dogs 3 and 4, hair bezoars were found in the proximal gut and this was considered responsible for their greater dilatation. The bowel was usually enlarged for at least $15 \mathrm{~cm}$ but in dog 3 the bowel extended $60 \mathrm{~cm}$ proximally. Table I shows the amount of thickening in the bowel wall. The circular muscle was increased in all dogs except the one which was sacrificed at 7 days, where dilatation rather than hypertrophy was found as would be expected. The longitudinal muscle coat was unchanged in three dogs, increased in the dog which had the greatest circular muscle thickening, and reduced in the dog which died at 7 days. Allowing for the effect of an increased circumference, the longitudinal muscle actually hypertrophied in four dogs, but not in ore.

Table II shows the results of the ganglion cell counts on the slides stained with the indoxyl esterase technique. No assessment was made on dog 1 who was sacrificed at seven days. In $\operatorname{dog} 3$, the proximal count was made twice, but because the technique was not entirely satisfactory for the first count it was repeated on the following day with tissue which had been stored at $5^{\circ} \mathrm{C}$ overnight. The number of ganglion cells was related to the total mass of longitudinal and circular muscle. In no instance did the ganglion cell count increase above the stenosis but in every case was reduced. This reduction varied from $50 \%$ to $20 \%$ and was more marked when the muscle hypertrophy was greatest.

Haematoxylin and eosin sections confirmed the massive increase of the circular muscle, but no attempt was made to assess whether muscle hyperplasia occurred. The individual ganglion cells were larger above the stenosis, in both Auerbach's and Meissner's plexus. This gave an impression that the actual number was increased.

\section{Discussion}

This work confirms previous studies showing that ganglion cells increase in size when the bowel is

\begin{tabular}{|c|c|c|c|c|c|c|c|}
\hline \multirow[t]{3}{*}{ Dog } & \multirow[t]{3}{*}{ Survival (day) } & \multicolumn{2}{|c|}{ Circumference $(\mathrm{cm})$} & \multicolumn{4}{|c|}{ Muscle Thickness (mm) } \\
\hline & & \multirow[b]{2}{*}{ Distal } & \multirow[b]{2}{*}{ Proximal } & \multicolumn{2}{|c|}{ Longitudinal } & \multicolumn{2}{|c|}{ Circular } \\
\hline & & & & Distal & Proximal & Distal & Proximal \\
\hline $\begin{array}{l}1 \\
2 \\
3 \\
4 \\
5\end{array}$ & $\begin{array}{r}7 \\
35 \\
63 \\
24 \\
21\end{array}$ & $\begin{array}{l}2 \cdot 8 \\
2 \cdot 8 \\
3 \cdot 0 \\
2 \cdot 5 \\
2 \cdot 7\end{array}$ & $\begin{array}{l}4 \cdot 8 \\
3 \cdot 4 \\
9 \cdot 5 \\
5 \cdot 8 \\
3 \cdot 0\end{array}$ & $\begin{array}{l}0.4 \\
0.5 \\
0.4 \\
0.4 \\
0.3\end{array}$ & $\begin{array}{l}0.2 \\
0.5 \\
0.5 \\
0.4 \\
0.3\end{array}$ & $\begin{array}{l}0.8 \\
0.8 \\
0.8 \\
0.8 \\
0.8\end{array}$ & $\begin{array}{l}0.75 \\
1.2 \\
1.4 \\
1.4 \\
1.0\end{array}$ \\
\hline
\end{tabular}

Table I The amount of thickening in the bowel wall 


\begin{tabular}{|c|c|c|c|c|c|c|c|}
\hline \multirow[t]{2}{*}{ Dog } & \multicolumn{2}{|c|}{$\begin{array}{l}\text { Volume of Tissue } \\
\text { Stained }\left(\mathrm{mm}^{3}\right)\end{array}$} & \multicolumn{2}{|c|}{$\begin{array}{l}\text { Total Ganglion } \\
\text { Cells Counted }\end{array}$} & \multicolumn{2}{|c|}{$\begin{array}{l}\text { Ganglion Cells } \\
\text { per } \mathrm{mm}^{3}\end{array}$} & \multirow[t]{2}{*}{$\begin{array}{l}\text { Percentage Decrease in } \\
\text { Proximal Ganglion Cells }\end{array}$} \\
\hline & Distal & Proximal & Distal & Proximal & Distal & Proximal & \\
\hline 2 & $315 \cdot 0$ & $\begin{array}{l}443 \cdot 2 \\
\text { First count }\end{array}$ & 23,730 & 20,496 & $75 \cdot 3$ & $46 \cdot 2$ & 39 \\
\hline \multirow[t]{2}{*}{$3^{1}$} & $219 \cdot 6$ & $\begin{array}{l}250 \cdot 7 \\
3757\end{array}$ & 16,093 & $\begin{array}{l}13,542 \\
15,515\end{array}$ & $73 \cdot 3$ & $\begin{array}{l}54 \cdot 0 \\
41 \cdot 3 \\
47 \cdot 7 \text { Mean }\end{array}$ & 35 \\
\hline & & $\begin{array}{l}\text { Second count } \\
2595 \\
286 \cdot 5 \\
328 \cdot 5\end{array}$ & & $\begin{array}{r}9,548 \\
12,507 \\
9,396\end{array}$ & & $\begin{array}{l}36 \cdot 8 \\
43 \cdot 7 \\
28 \cdot 6 \\
36.4 \text { Mean }\end{array}$ & 51 \\
\hline 4 & $217 \cdot 2$ & $\begin{array}{l}4284 \\
356.4\end{array}$ & 30,395 & $\begin{array}{r}17,542 \\
8,959\end{array}$ & 139.9 & $\begin{array}{l}40.9 \\
25 \cdot 1 \\
33 \cdot 0 \text { Mean }\end{array}$ & 77 \\
\hline 5 & $297 \cdot 0$ & $351 \cdot 0$ & 30,552 & 27,875 & 102.9 & $79 \cdot 4$ & 23 \\
\hline
\end{tabular}

Table II Results of ganglion cell counts

${ }^{1}$ The proximal count was taken twice (see text).

obstructed and that the smooth muscle of the dilated gut becomes thicker. Filogamo has published the most detailed studies on this hypertrophy (Filogamo and Vigliani, 1954; Filogamo, 1955), using $7 \mu$ sections stained with methyl-pyronin green, the increase in ganglion cell size was given as a normogram based on nuclear size. He quotes Miura as having first seen this hypertrophy in 1913, and it has also been confirmed by others (Ambrosi, 1942; Benninghoff, 1951). The ganglion cells in Meissner's plexus show a greater hypertrophy than those in Auerbach's plexus, but this may only be because they are normally more easily visible (Sauer and Rumble, 1946).

The results of the present study do not confirm previous experiments which have demonstrated hyperplasia of ganglion cells. In this study no increase in the number of ganglion cells in Auerbach's plexus was found. Although a decrease in the number was discovered when the ratio of ganglion cells to volume of muscle was calculated, it will be seen from Table II that, if this is corrected to allow for muscle hypertrophy, there is probably no actual decrease in the number of ganglion cells. They are only less frequent because of the muscle hypertrophy. This result does not agree with previous work in animals (Ambrosi, 1942; Benninghof, 1951; Filogamo and Vigliani, 1954; Filogamo, 1955). All these authors found an increase in the number of ganglion cells above an obstruction. In no instance, however, was any mitosis of a ganglion cell seen, so it was presumed that the increased number arose from immature stored elements in Auerbach's plexus. The discrepancy between the results of the present study and previous ones may be caused by the difference in techniques used for counting. Others have counted ganglion cells after staining $7 \mu$ sections with special stains which emphasize Nissl's granules and enable them to be more easily recognizable, but in spite of this small ganglion cells would still be difficult to recognize with certainty. The indoxyl esterase technique is a histochemical method which is simply based on the deposition of a blue indoxyl dye where cholinesterase is present. If the mucosa and muscularis mucosa are removed from a piece of gut, the only cells present to be stained preferentially are those lying between the smooth and longitudinal muscle in Auerbach's plexus. The great advantage of this method is that very large areas can easily be searched for nervous tissue in $100 \mu$ sections, compared with the smaller area and the more diffcult identification in conventional $7 \mu$ sections.

The difference between the results of this study and those showing a hyperplasia of ganglion cells may not be incompatible if the apparent hyperplasia in fact arose from immature stored cell elements as suggested by Filogamo. There is great controversy over the type and number of cells which constitute Auerbach's plexus. The large ganglion cells can be recognized easily with haematoxylin and eosin, methyl blue, or cresyl violet stains because of their large size and Nissl granules. Silver staining enables the dendritic processes to be recognized so that the large cells can be divided according to Dogiel's criteria. The small cells, usually called interstitial cells of Cajal, form the majority of the remainder. There are great differences of opinion on these cells; most consider them to be undefined neural tissue, others call them Schwann cells (Smith, 1967) and others, using electron microscopy, fibroblasts (Richardson, 1961). In spite of this uncertainty it can be presumed that these are the immature stored cell elements postulated as the source of the in- 
creased ganglion cell count. It is possible that these cells can be stained with the indoxyl esterase technique, but further studies will be necessary to prove this. If this were so, the results of the present study combined with those previously done, support a statement that on conventional staining there is an apparent increase in the number of ganglion cells in the hypertrophied gut proximal to a stenosis, due to the development of immature stored cell elements into mature neurones. There is no actual true increase in ganglion cell numbers because mitoses have never been seen and the total number of cells in Auerbach's plexus does not appear to have increased.

This deduction is significant in several diseases of the bowel. Ganglion cells are seen more frequently in regional enteritis (Davis et al, 1955) and ulcerative colitis (Storsteen et al, 1953). In both conditions there may be overactivity of the bowel combined with either a true or an apparent hypertrophy of the muscle caused by contraction of the gut, and experimental work would support an apparent increase in ganglion cell numbers. But in several diseases with smooth muscle hypertrophy, such as diffuse spasm of the oesophagus and hypertrophic pyloric stenosis, there is no such increase, but on the contrary decreased numbers or abnormalities are found in the neural tissue. Also, in Chagas disease, smooth muscle hypertrophy is found in the gut associated with decreased ganglion cells. In this disease, although a transition from hypertrophy of a hollow organ to the dilated stage of megacolon or megaoesophagus has never been exactly followed, there is sufficient circumstantial evidence to suggest that the hypertrophy represents compensation and dilatation decompensation of uncoordinated gut which has had its ganglion cells destroyed.

It is suggested that there are two types of smooth muscle hypertrophy in the gut. The first is associated with an apparent increase in the number of ganglion cells. In these diseases there is either obstruction distally or the bowel is overactive for some other reason, as in ulcerative colitis or regional enteritis. The second is associated with a decrease in the number of ganglion cells and frequent abnormalities. In these diseases the bowel is hypertrophied to compensate for its inefficiency, which is caused by the ganglion cell changes. This occurs in Chagas disease and may possibly account for congenital pyloric stenosis and diffuse oesophageal spasm.

I am grateful to Professor H. D. Ritchie and Professor I. Doniach for the facilities to do this work and to $\mathrm{Mr} \mathrm{K}$. Swettenham for his technical assistance.

\section{References}

Ambrosi, F. (1942). Sulle alterazioni istologiche dei gangli e dei nervi del tubo digerente nella occlusione intestinale. Ricerche nell'uomo e sperimentali. Arch. de Vecchi Anat.pat., 5, 215-240.

Benninghoff, A. (1951). Vermehrung und Vergrösserung von Nervenzellen bei Hypertrophie des Innervationsgebietes. Z. Naturforsch., 6, 38-41.

Davis, D. R., Dockerty, M. B., and Mayo, C. W. (1955). The myenteric plexus in regional enteritis: a study of the number of ganglion cells in the ileum in 24 cases. Surg. Gynec. Obstet., 101, 208-216.

Earlam, R. J., Schlegel, J. F., and Ellis, F. H., Jr. (1967). Effect of ischemia of lower esophagus and esophagogastric junction on canine esophageal motor function. J. thorac. cardiovass. Surg., 54, 822-831.

Filogamo, G. (1955). Iperplasia ed ipertrofia delle cellule gangliari del plesso sottomucoso (di Meissner) nel cane, in condizioni sperimentali. Riv. Biol., 47, 331-342.

Filogamo, G., and Vigliani, F. (1954). Richerche sperimentali sulla correlazione tra estensione del territorio di innervazione e grandezza e numero delle cellule gangliare del plesso mienterico (di Auerbach) nel cane. Riv. Pat. nerv. ment., 75, 441-472.

Holt, S. J., and Withers, R. F. J. (1952). Cytochemical localization of esterases using indoxyl derivatives. Nature (Lond.), 170, 10121014.

Richardson, K. C. (1958). Electronmicroscopic observations on Auerbach's plexus in the rabbit, with special reference to the problem of smooth muscle innervation. Amer. J. Anat., 103 99-135.

Sauer, M. E., and Rumble, C. T. (1946). The number of nerve cells in the myenteric and submucous plexuses of the small intestine of the cat. Anat. Rec., 96, 373-81.

Smith, B. (1967). Effect of irritant purgatives on the myenteric plexus in man and the mouse. Gut, 9, 139-143.

Storsteen, K. A., Kernohan, J. W., and Bargen, J. A. (1953). The myenteric plexus in chronic ulcerative colitis. Surg. Gynec. Obstet., 97, 335-343. 